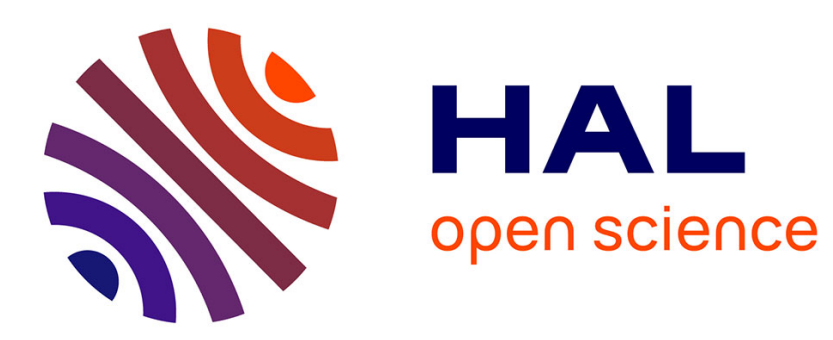

\title{
A theoretical exploration of dietary collective medication in social insects
}

Laure-Anne Poissonnier, Mathieu Lihoreau, Tamara Gomez-Moracho, Audrey

Dussutour, Jerome Buhl

\section{- To cite this version:}

Laure-Anne Poissonnier, Mathieu Lihoreau, Tamara Gomez-Moracho, Audrey Dussutour, Jerome Buhl. A theoretical exploration of dietary collective medication in social insects. Journal of Insect Physiology, 2018, 106, pp.78-87. 10.1016/j.jinsphys.2017.08.005 . hal-02105099

\section{HAL Id: hal-02105099 \\ https://hal.science/hal-02105099}

Submitted on 4 Jan 2021

HAL is a multi-disciplinary open access archive for the deposit and dissemination of scientific research documents, whether they are published or not. The documents may come from teaching and research institutions in France or abroad, or from public or private research centers.
L'archive ouverte pluridisciplinaire HAL, est destinée au dépôt et à la diffusion de documents scientifiques de niveau recherche, publiés ou non, émanant des établissements d'enseignement et de recherche français ou étrangers, des laboratoires publics ou privés. 


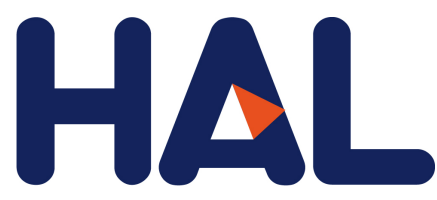

archives-ouvertes

\title{
A theoretical exploration of dietary collective medication in social insects
}

\author{
Laure-Anne Poissonnier, Mathieu Lihoreau, Tamara Gomez-Moracho, Audrey \\ Dussutour, Jerome Buhl
}

\section{To cite this version:}

Laure-Anne Poissonnier, Mathieu Lihoreau, Tamara Gomez-Moracho, Audrey Dussutour, Jerome Buhl. A theoretical exploration of dietary collective medication in social insects. Journal of Insect Physiology, Elsevier, 2018, 106, pp.78-87. 10.1016/j.jinsphys.2017.08.005 hal-02105099

\section{HAL Id: hal-02105099 \\ https://hal.archives-ouvertes.fr/hal-02105099}

Submitted on 4 Jan 2021

HAL is a multi-disciplinary open access archive for the deposit and dissemination of scientific research documents, whether they are published or not. The documents may come from teaching and research institutions in France or abroad, or from public or private research centers.
L'archive ouverte pluridisciplinaire HAL, est destinée au dépôt et à la diffusion de documents scientifiques de niveau recherche, publiés ou non, émanant des établissements d'enseignement et de recherche français ou étrangers, des laboratoires publics ou privés. 


\title{
A theoretical exploration of dietary collective medication in social insects
}

\author{
Laure-Anne Poissonnier ${ }^{\mathrm{a}, 1}$, Mathieu Lihoreau ${ }^{\mathrm{b}, 1, *}$, Tamara Gomez-Moracho ${ }^{\mathrm{b}}$, Audrey Dussutour ${ }^{\mathrm{b}}$, \\ Jerome Buhl ${ }^{\mathrm{a}}$ \\ a School of Agriculture, Food and Wine, Waite campus, The University of Adelaide, SA 5005, Australia \\ ${ }^{\mathrm{b}}$ Research Center on Animal Cognition (CRCA), Center for Integrative Biology (CBI), University Paul Sabatier, CNRS, UPS, France
}

\section{A R T I C L E I N F O}

\section{Keywords:}

Individual-based model

Nutritional geometry

Nutritional immunology

Social immunity

Social insects

\begin{abstract}
A B S T R A C T
Animals often alter their food choices following a pathogen infection in order to increase immune function and combat the infection. Whether social animals that collect food for their brood or nestmates adjust their nutrient intake to the infection states of their social partners is virtually unexplored. Here we develop an individual-based model of nutritional geometry to examine the impact of collective nutrient balancing on pathogen spread in a social insect colony. The model simulates a hypothetical social insect colony infected by a horizontally transmitted parasite. Simulation experiments suggest that collective nutrition, by which foragers adjust their nutrient intake to simultaneously address their own nutritional needs as well as those of their infected nestmates, is an efficient social immunity mechanism to limit contamination when immune responses are short. Impaired foraging in infected workers can favour colony resilience when pathogen transmission rate is low (by reducing contacts with the few infected foragers) or trigger colony collapse when transmission rate is fast (by depleting the entire pool of foragers). Our theoretical examination of dietary collective medication in social insects suggests a new possible mechanism by which colonies can defend themselves against pathogens and provides a conceptual framework for experimental investigations of the nutritional immunology of social animals.
\end{abstract}

\section{Introduction}

Animals select foods in order to reach physiological states maximising growth, reproduction, metabolic health and survival, depending on their sex, age, and reproductive status (Lee et al., 2008; Solon-Biet et al., 2015). Nutrient regulatory behaviours have been most effectively studied using nutritional geometry, a conceptual framework for modelling the nutritional interactions between animals and their environments (Simpson and Raubenheimer, 1993, 2012). In this approach, the challenge for the animals is to regulate their intake of multiple nutrients simultaneously (typically but not necessarily, the macronutrients protein, carbohydrates and fat) at amounts and balances enabling them to maintain nutritional states maximising fitness traits. This optimal intake is known as the nutrient 'intake target' (Simpson et al., 2015a). The multi-dimensional aspect of nutritional geometry is critical for capturing the complexity of animal nutritional decisions, by breaking down food intake into specific amounts and ratios of nutrients that can have independent and/or interacting effects on the physiology and behaviour of animals (Simpson et al., 2015b).

Several recent studies based on this framework show how animals can dynamically adjust their nutrient intake following an infection in order to boost their immune system and combat parasites or pathogens (Ponton et al., 2011, 2015). For instance, many insects increase their intake of dietary protein required for the synthesis of peptides in immune pathways (Lee et al., 2006; Povey et al., 2009; Povey et al., 2014; Mason et al., 2014). This behavioural response is analogous to selfmedication, when sick animals ingest specific substances that are not usually part of their diets (Clayton and Wolfe, 1993; de Roode et al., 2013). In these individuals, the selective ingestion of curative substances in food produces measurable benefits to host fitness and negative effects on the pathogen.

While most research on dietary self-medication has been conducted on solitary animals (Abbot, 2014) or isolated individuals in the lab (Lee et al. 2006; Peck et al., 1992), nutrient balancing may also constitute a highly efficient, yet unexplored, mechanism to limit pathogen spread in animal groups, where the increased rate of contact between individuals induces a higher susceptibility to pathogens (Schmid-Hempel, 2017). In social animals the nutritional decisions of an individual not only depends on its own nutritional needs but also critically on the needs of other group members, as individuals will either cooperate or compete to access food (Lihoreau et al., 2015). Recent applications of nutritional geometry to social species indicate that animals can efficiently track

\footnotetext{
* Corresponding author at: Centre de Recherches sur la Cognition Animale (UMR CNRS 5169), Bât 4R3, Université Paul Sabatier, 118 route de Narbonne, 31400 Toulouse, France.

E-mail address: mathieu.lihoreau@univ-tlse3.fr (M. Lihoreau).

${ }^{1}$ These authors contributed equally to the work.
} 
(a)

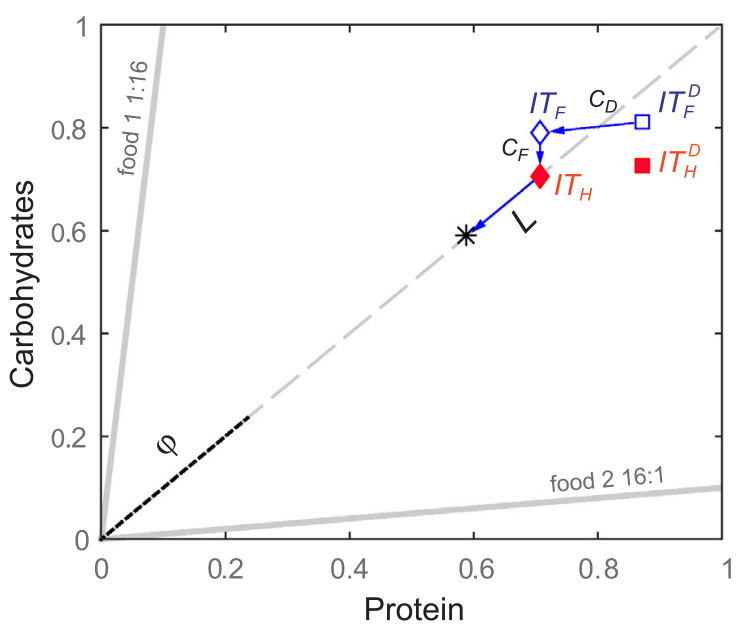

(b)

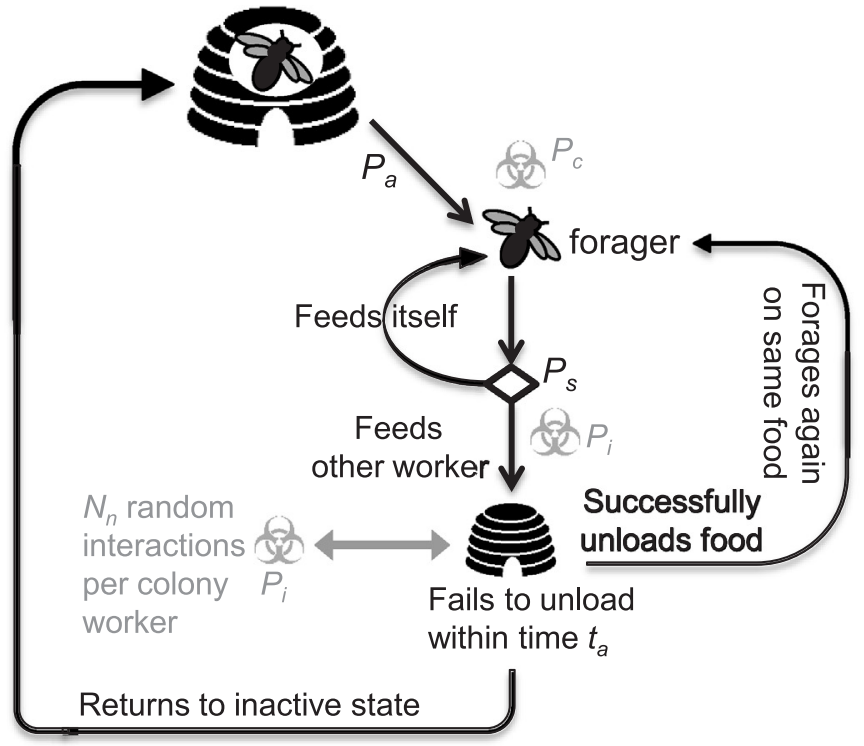

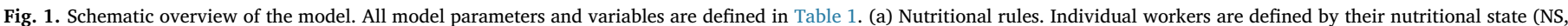

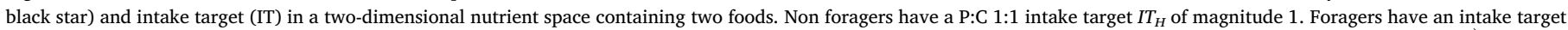

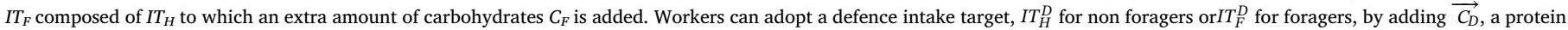

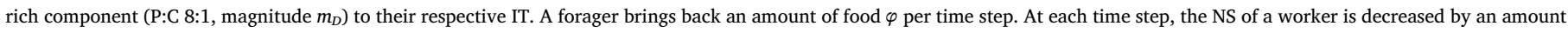

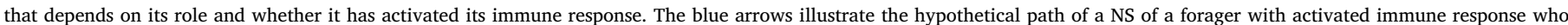

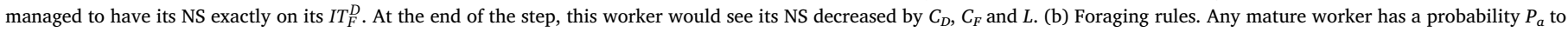

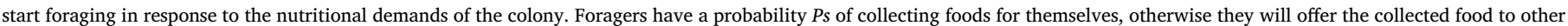

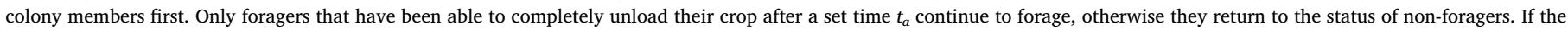

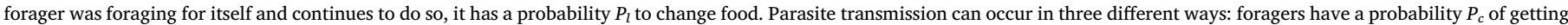

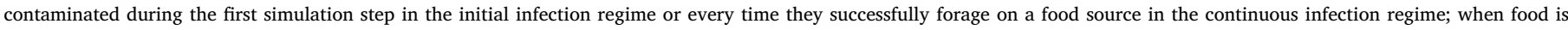

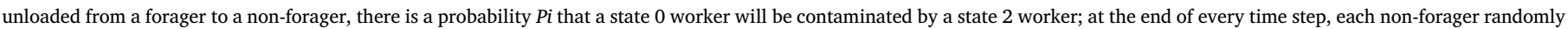

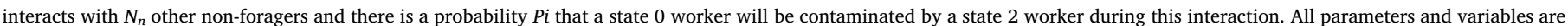
defined in Table 1.

their own nutritional needs in various social contexts, as evidenced by self-selection diet experiments (Dussutour and Simpson, 2009; Hendriksma and Shafir, 2016) and simulations of individual-based models (Lihoreau et al., 2014, Senior et al., 2015; 2016a). However, whether social animals can respond to the infection states of their social partners by adjusting their nutrient intake in order to feed conspecifics and combat pathogen invasion has not been established.

The question of dietary collective medication is especially relevant in social insects, such as bees and ants, that exhibit high levels of social complexity (Holldobler and Wilson, 2009). In these animal groups, individuals specialised in food collection (foragers) must regulate a nutrient intake target to a colony level comprising the needs of all the workers (e.g. nurses, guards), the breeders (e.g. queens, drones) and the brood (larvae), without a global knowledge of the intake targets of their nestmates, nor of the food stores in the colony (Behmer, 2009; Feldhaar, 2014). Disease transmission has been mainly explored in bees due to the fact that parasites and pathogens are major causes of population declines (Goulson et al., 2015; Klein et al., 2017). Social bees are infected by a wide range of viruses, protozoans, bacteria, mites, fungi and parasitoid insects, against which they have evolved behavioural strategies to prevent infection and limit contamination (SchmidHempel, 1998). At the individual level, foragers can adjust food collection, for instance by prioritising flowers with nectar rich in secondary metabolites to combat gut parasites (Baracchi et al., 2015) or collecting resins containing antimicrobial substances to limit the spread of fungus within colonies (Simone-Fintrom et al., 2012). At the collective level, bees also display a range of social immunity responses (Cremer et al., 2007) that include grooming (Büchler et al., 1992), social exclusion of infected nestmates (Waddington and Rothenbuhler, 1976, Baracchi et al., 2012), spatial segregation (Naug and Smith, 2007) and thermo-modulation to heat-kill pathogens (Starks et al., 2000). Although there is no direct evidence for a change of nutrient intake target in infected bees (de Grandi-Hoffman and Chen, 2015), honey bees and bumblebees are able to accurately balance their intake of multiple nutrients (i.e. carbohydrates and free amino acids in nectar, protein and lipids in pollen) (Altaye et al., 2010; Hendriksma and Shafir 2016; Vaudo et al., 2016a; Stabler et al., 2015) and protein intake modifies baseline immune-competence levels in adults (honey bees: Alaux et al., 2010), thus setting the stage for dietary collective medication in these social insects. Recently, it was shown that honey bees infected with microsporidians Nosema spp. increase their intake of sugar syrup containing amino-acids, presumably to support their immune responses (Martín-Hernández et al., 2011; Lach et al., 2015).

Here we developed an individual-based model of nutritional geometry to explore the impact of dietary collective medication on a pathogen spread in a social insect colony. The model simulates a hypothetical social insect colony infected by a hypothetical horizontally transmitted parasite, inspired from the well-described interactions between honey bee (Apis mellifera) and Nosema ceranae (Higes et al., 2013). In this host parasite system, infected workers start foraging earlier in life (Goblirsch et al., 2013; Natsopoulou and McMahon, 2014), increase their number of daily foraging trips (Alaux et al., 2014; Wells et al., 2016) and spend more time outside the colony (Alaux et al., 2014; Wolf et al., 2014; Kralj and Fuchs, 2010). The reduced foraging workforce is compensated with the premature onset of foraging by young workers that have cognitive deficits (Vance et al., 2009; Ushitani et al., 2016), potentially leading to colony collapse (Russel et al., 2013). Using our model, we examined the influence of the immune response duration on the efficiency of collective dietary medication. Next, we described the impact of foraging failure related to pathogen virulence on parasite spread. Our aim was not to provide a quantitative model of bee-parasite interactions but rather to propose a new theoretical approach for social insect nutritional immunology that could guide future experimental research. 
Table 1

Model parameters, variables, their notations and values.

\begin{tabular}{|c|c|c|c|}
\hline variable/parameter & notation & description & Value \\
\hline Total number of steps in a simulation & Ts & Duration of a simulation in steps & $T s=2000$ \\
\hline Number of mature workers & $n_{m}$ & $\begin{array}{l}\text { Number of mature workers, which can either be foragers or remain } \\
\text { in the nest }\end{array}$ & $n_{m}=400$ \\
\hline Number of foragers & $n_{f}$ & Number of mature workers which are foraging & Variable \\
\hline Number of immature workers & $n_{j}$ & $\begin{array}{l}\text { Number of workers in the nest which can never engage in foraging } \\
\text { activity }\end{array}$ & $n_{j}=100$ \\
\hline Nutritional state & NS & $\begin{array}{l}\text { An agent's nutritional state, as tracked by its }(p, c) \text { position in the } \\
\text { nutrient space, and denoting total intake of the two nutrients. }\end{array}$ & $\begin{array}{l}\text { Variable }(p, c) \text { and initialised at the value of the } \\
\text { individual's intake target }\end{array}$ \\
\hline Intake target & IT & $\begin{array}{l}\text { An agent's IT is the }(p, c) \text { coordinate in the nutrient space that } \\
\text { maximizes fitness }\end{array}$ & $\begin{array}{l}I T_{H}=(0.707,0.707) \\
I T_{F}=(0,707,0.715) \\
I T_{H}^{D}=(0.724,0.709) \\
I T_{F}^{D}=(0.724,0.717)\end{array}$ \\
\hline Nutritional performance & $D$ & The Euclidean distance between an agent's NS and the IT. & Variable \\
\hline Food rail slope & $V$ & $\begin{array}{l}\text { The nutritional composition of a food in terms of the amount of } \\
\text { carbohydrate }(c) \text { in a given food relative to single equivalent unit of } \\
\text { protein }(p) \text {. }\end{array}$ & Food 1: $V=16$ Food 2: $V=1 / 16$ \\
\hline Appetite & $A$ & $\begin{array}{l}\text { The amount of a given food that an agent would consume to } \\
\text { minimize } D \text {. }\end{array}$ & Variable \\
\hline Current/ideal food rail angle & $\alpha_{f}, \alpha_{\text {ideal }}$ & $\begin{array}{l}\alpha_{i d e a l} \text { and } \alpha_{f} \text { are the angles associated with the ideal rail joining the } \\
\text { NS and the IT of the individual and with the food rail f respectively }\end{array}$ & Variable \\
\hline Food ingested & $\varphi$ & $\begin{array}{l}\text { The maximum amount of food that an agent is able to consume at a } \\
\text { given time. }\end{array}$ & $\varphi=0.2$ \\
\hline Cost of life & $L$ & $\begin{array}{l}\text { Amount by which the NS are decreased at each time step along a } \\
\text { food rail of P:C 1:1 }\end{array}$ & $L=\varphi / 12=0.0167$ \\
\hline Cost of foraging & $C_{F}$ & Additional carbohydrate cost for foraging & $C_{F}=L / 2=0.0083$ \\
\hline Cost of immune response & $C_{D}, m_{D}$ & $\begin{array}{l}C_{D} \text { represents the cost of the immune response and is a vector along } \\
\text { a food rail of P:C 8:1 and of magnitude } m_{D}\end{array}$ & $m_{D}=L=0.0167$ \\
\hline $\begin{array}{l}\text { Probability to start foraging and } \\
\text { associated constant }\end{array}$ & $P_{a}, K_{a}$ & $P_{a}$ is the probability to start foraging & $\begin{array}{l}P_{a}=e^{<D>\times K_{a-1}} \\
K_{a}=2\end{array}$ \\
\hline $\begin{array}{l}\text { Probability for a forager of collecting } \\
\text { foods for itself }\end{array}$ & $P_{s,} K_{S}$ & $P_{S}$ is the of collecting foods to address a forager's own requirements & $\begin{array}{l}P_{S}=e^{D \times K_{S}-1} \\
K_{S}=4.5\end{array}$ \\
\hline Foraging giving up time & $T_{a}$ & $\begin{array}{l}\text { Time after which a worker will give up foraging and return to the } \\
\text { status of worker in the nest if it did not unload the food it brought } \\
\text { back to the nest }\end{array}$ & $T_{a}=6$ \\
\hline $\begin{array}{l}\text { Probability for a forager to leave a food } \\
\text { while foraging for itself }\end{array}$ & $P_{L}$ & $\begin{array}{l}\text { Probability Pl to change food according to the difference between } \\
\text { the current food rail it exploits and the ideal angle linking its NS and } \\
\text { IT }\end{array}$ & $P_{L}=\frac{\left|\alpha_{\text {ideal }}-\alpha_{f}\right|}{\pi / 2}$ \\
\hline Probability of forager's contamination & $P_{c}$ & $\begin{array}{l}\text { Probability for a forager to be contaminated with the pathogen } \\
\text { when it successfully brings food back to the nest }\end{array}$ & $\begin{array}{l}\text { Initial contamination: } \\
P_{C}=0.2 \text { Continuous contamination: } P_{C}=0.001\end{array}$ \\
\hline $\begin{array}{l}\text { Probability of becoming contaminated } \\
\text { during interactions }\end{array}$ & $P i$ & $\begin{array}{l}\text { Probability of becoming contaminated (state } 1 \text { ) by an interaction } \\
\text { with an infected worker (state 2) }\end{array}$ & $\begin{array}{l}P_{i}=0.0025 \text { (default), } 0.01 \text { (fast pathogen spread } \\
\text { simulations) }\end{array}$ \\
\hline Probability for the infection to worsen & $P_{W}, K_{W}$ & Probability that an individual's state worsen from state 1 to 2 & $\begin{array}{l}P_{W}=e^{D \times K_{W}-1} \\
K_{W}=6\end{array}$ \\
\hline Probability for the infection to ease & $P_{R}$ & Probability that an individual in state 2 returns to state 1 & $\begin{array}{l}P_{R}=e^{-D \times K_{R}} \\
K_{R}=25\end{array}$ \\
\hline Immune response time & $T_{d}$ & $\begin{array}{l}\text { Time during which an individual engages its immune response } \\
\text { (workers cannot recover or die) }\end{array}$ & $T d=2,5,20,200,500$ \\
\hline $\begin{array}{l}\text { Probability of engaging in a social } \\
\text { immune response }\end{array}$ & $P_{D}$ & $\begin{array}{l}\text { Probability that an individual in state } 0 \text { or } 1 \text { activates its immune } \\
\text { response when interacting with a state } 2 \text { individual }\end{array}$ & $P_{D}=0.0,0.01,0.05,0.25,0.5,0.75,1$ \\
\hline Probability of failing to forage & $P_{f}$ & $\begin{array}{l}\text { The probability that an infected (state } 2 \text { ) bee will fail to forage for a } \\
\text { simulation step }\end{array}$ & $P_{f}=0.25$ (default), $0,0,0.1,0.35,0.50 .75$ \\
\hline
\end{tabular}

\section{Model}

\subsection{Model overview}

We developed an individual-based model of nutritional geometry to explore dietary collective medication in a social insect colony infected with a horizontally transmitted parasite (Fig. 1). In the model, the pathogen is transferred by passive contacts between individuals inside the colony. Each individual can be in a pathogen free state (state 0), contaminated at low level (state 1) or seriously infected (state 2). State 2 individuals are contagious and can fail foraging. All individuals have a normal intake target for protein and carbohydrates. Once infected, however, individuals adopt a defence intake target that is higher in protein. This defence target provides individuals with a better resistance to the pathogen. Uninfected foragers can detect infected nestmates and also adopt a defence intake target to engage in social immunity (Fouks and Lattorf, 2011). In what follows we describe the rules for nutritional decisions, foraging choices, pathogen spread and defence response. All parameters and variables are defined in Table 1.

\subsection{Nutritional decisions}

Individual workers are defined by their nutritional state (NS, the amount and ratio of nutrients ingested and available to the worker at a certain time, which changes every step) and nutrient intake target (IT, the amount and ratio of nutrients that the worker must reach to maximize fitness, according to its activity and infectious status) in a twodimensional nutrient space defined by protein $\mathrm{P}$ ( $\mathrm{x}$-axis) and carbohydrates C (y-axis; Fig. 1a). Note that while we focused on two nutrients for which social insect regulatory behaviour have been best characterised (Dussutour and Simpson, 2009; Altaye et al., 2010; Hendriksma and Shafir, 2016), a similar approach could be readily extended to different nutrients or more nutrients simultaneously (Simpson and Raubenheimer, 2012). The nutritional environment is 
composed of two foods each represented by a nutritional rail $V$ with a specific ratio of $\mathrm{P}$ to $\mathrm{C}(\mathrm{P}: \mathrm{C})$. Instead of simulating natural food resources (Nicolson, 2011; Vanderplanck et al., 2017), in this theoretical exploration we used a C-rich food (P:C 1:16) and P-rich food (P:C 16:1) with extreme $\mathrm{P}: \mathrm{C}$ ratios in order to cover a broad nutrient space.

The colony is composed of 500 individuals. To account for the agedbased division of labour of many social insects (Holldobler and Wilson, 2009), we simulated two types of individuals. The immature workers $(\mathrm{Nj})$ stay in the nest and never undertake foraging. The mature workers $\left(N_{m}\right)$ can dynamically shift between staying in the nest and foraging, in accordance with the nutritional demands of the colony. Workers have different ITs depending on their foraging activity and whether they defend themselves against the pathogen (Fig. 1a). Non-foraging workers (mature and immature workers) have a P:C 1:1 intake target $I T_{H}$ of magnitude 1. Foragers (mature workers) have an intake target $I T_{F}$ composed of $I T_{H}$ to which an extra amount of carbohydrates $C_{F}$ is added, to account for their increased need of energy to travel and collect resources. When insects defend themselves against the pathogen they adopt a defence intake target, $I T_{H}^{D}$ for non-foraging workers or $I T_{F}^{D}$ for foragers, by adding $\overrightarrow{C_{D}}$, a protein rich component (P:C 8:1, magnitude $m_{D}$ ) to their respective IT. This increase of protein replicates the observed behavioural response of many insects following an infection (Lee et al., 2006; Povey et al., 2009; Povey et al., 2014; Mason et al., 2014). Note that similar simulations could have been run with an increase of carbohydrate as some parasites can also induce an energetic stress to the host (Mayack and Naug, 2010). At the beginning of a simulation all workers have their NS initialised at their respective IT. Their NS can then increase (the bees acquire food) or decrease (the bees used part of their resources) at each time step. Again these values were chosen for the sake of simplicity and do not necessarily reflect the intake target of real workers.

When foraging, insects carry an amount $\varphi$ of food which is a fraction of the initial IT magnitude $\left|I T_{H}\right|\left(\varphi=\left|I T_{H}\right| / 5\right.$ in our simulations $)$ (Fig. 1a). The amount $L$ by which the NS are decreased at each time step is itself set as a fraction of $\varphi(L=\varphi / 12$ in our simulations). In effect, this means that a fully loaded forager could provide food for itself and for another nestmate for six time steps before being empty if these individuals were at a distance $L$ from their IT (i.e. they were previously on their IT and had their NS decreased by $L$ for one step before being fed). Alternatively, the forager could provide enough food for one nestmate to return to its IT if it had not received food for 12 steps (provided that the food itself would point directly to the IT). The magnitude of the extra-costs for foraging and the immune defence were also set in relation to $L$ with $C_{F}=L / 2$ and $m_{D}=L / k_{D}$ (with $k_{D}=1$ ) in all simulations.

$D$, is the Euclidian distance between the NS and IT of an individual. $D$ is a proxy of the nutritional performance of the individual (i.e. ability to track its IT). In the context of nutritional geometry, the lower $D$ the higher the fitness of the individual (Senior et al. 2015, 2016b). In our model, insects use a 'closest distance' rule of compromise (ROC), meaning that foods are consumed to minimize $D$, to decide when to stop eating or receiving a meal. This parsimonious rule, in which individuals can over eat one nutrient while under eating the other up to a certain point, has been observed in many animals and has the advantage of making the same assumption for both nutrients (Simpson and Raubenheimer, 2012). The amount of food that an individual ideally needs to consume from a given food, its appetite $A$, is calculated as follows:

$A=\min \left\{\varphi, D\left|\alpha_{\text {ideal }}-\tan ^{-1} V\right|\right\}$

where $\varphi$ is the maximum amount of food an individual can eat on one time step, $\alpha_{\text {ideal }}$ is the angle of a hypothetical 'ideal' food rail connecting an individual's NS to its IT, and $V$ is the food rail of the food being consumed.

\subsection{Foraging decisions}

Any mature worker has a probability $P_{a}$ to start foraging in response to the global nutritional demands of the colony (Fig. 1b). $P_{a}$ increases with average $D$ as follows:

$P_{a}=e^{<D>\times K_{a-1}}$

where $K_{a}$ is a constant.

Foragers have a probability $P_{S}$ of collecting foods for themselves. Otherwise they will offer the collected food to other colony members first (Fig. 1b). $P_{S}$ increases with the forager's $D$ as follows:

$P_{S}=e^{D \times K_{S}-1}$

When an individual forages for others, it first attempts to unload its crop to a randomly chosen worker in the nest. This individual accepts as much food as allowed by its ROC. If the individual does not accept the whole meal, the forager can consume part of the load according to its own ROC. If its crop is still not empty the forager waits until the next step to unload any remaining food using the same procedure, to another randomly chosen worker in the nest and then potentially consuming part of the remaining food for itself again. The outcome of these interactions between foragers and non-foraging workers in the nest is what provides a social feedback for the foragers to choose whether to continue the task. Only foragers that have been able to completely unload their crop after a set time $t_{a}$ continue to forage, otherwise they return to the status of workers in the nest (Fig. 1b). If the forager was foraging for itself and continues to do so, it has a probability $P_{l}$ to change food according to the difference between the current food rail it exploits and the ideal angle linking its NS and IT:

$P_{L}=\frac{\left|\alpha_{\text {ideal }}-\alpha_{f}\right|}{\pi / 2}$

where $\alpha_{i d e a l}$ and $\alpha_{f}$ are the angles (in radians) associated with the ideal rail joining the NS and the IT of the individual and with the food rail $f$ respectively.

\subsection{Pathogen spread}

Each worker can be in a pathogen free state (state 0), contaminated but with low levels of infection (state 1), or seriously infected (state 2). In the model, no individual can die or definitely leave the colony. Pathogen spread was simulated in three different ways.

Infection initially occurs through direct contacts between foragers and food. Contamination could be either initial or continuous. In the 'initial contamination' regime, foragers have a probability $P_{c}(P c=0.2)$ to become contaminated only during the first simulation step. In the 'continuous contamination' regime, foragers have a probability $P_{c}$ ( $P c=0.001)$ to become contaminated at each simulation step.

Infection can also happen through interactions between foragers and workers in the nest during food exchanges. When state 0 workers interact with state 2 workers (see below), state 0 workers have a probability $P_{i}$ of getting infected.

Finally, infection can occur via passive contacts between workers in the nest. On each time step, each worker in the nest randomly draws a number $\mathrm{Nn}$ of other nestmates to interact with, with a constant probability $P_{i}$ to infect or to be infected by their partner following the same rules as with interactions between foragers and non-foraging workers.

\subsection{Defence rules}

On each time step, state 1 workers have a probability $P_{w}$ of seeing their infection state worsen to state 2 .

$P_{W}=e^{D \times K_{W}-1}$

Individuals that turn into state 2 then immediately adopt their defence intake target $I T_{D}$. State 2 workers have a probability $P_{R}$ to 
decrease their pathogen load and revert to state 1 , and this probability is inversely proportional to $D$.

$P_{R}=e^{-D \times K_{R}}$

When this happens, the recovering worker continues to engage its immune response for $T_{d}$ time steps. During this time $T_{d}$ the infection state of workers cannot worsen to state 2 . However workers can revert from state 2 to state 1 . The higher $T_{d}$ the longer the immune response duration. Using different values of $T_{d}$ is analogous to triggering different components of the insect immune system. A low $T_{d}$ replicates an innate immune response whereas a high $T_{d}$ is more similar to an adaptive immune response (Schmid-Hempel, 1998).

State 2 workers also potentially suffer from a decreased foraging efficiency due to their heavy infection rates. On each time step, foragers have a probability $P f$ of failing to bring back food to the nest. In this case, workers must wait for the next step until they attempt foraging again. This simulates the impaired foraging performances of insects infected with parasites (Gómez-Moracho et al., 2017).

At the collective level, workers that are not yet infected (state 0 ) or just contaminated (state 1 ) have a probability $P_{D}$ to engage in a social immune response by adopting their defence intake target $I T^{D}$ whenever they interact with a seriously infected worker (state 2). Through social immunity, foragers can adjust their nutrient intake to prepare themselves to fight a potential contamination and to address the needs of infected nestmates and help them recover.

\subsection{Simulations and analyses}

All simulations and statistical analyses were conducted in Matlab. We ran simulations with either an initial contamination regime (contamination during the first simulation step only) or a continuous contamination regime (contamination at each simulation steps).

Each simulation ran for 2000 steps and was replicated 250 times (26250 simulations in total). We used populations of 500 insects (100 immature workers, 400 mature workers) with $40 \%$ of foragers at the beginning of the simulation ( 200 workers in the nest +200 foragers). For each simulation, we measured variables related to pathogen spread (number of infected individuals in state 1 , state 2 and state $1+2$ ), colony nutritional performance (average $D$ ) and colony foraging effort (final number of foragers $n_{f}$, total number of foraging trips accomplished by all foragers $n_{T}$ ).

We conducted two-way analyses of variances (ANOVAs) on these results to test the effects of the immune response duration $\left(T_{d}\right)$, the probability to engage in a social immune response $\left(P_{D}\right)$ and their interaction on state 1 , state 2 , state $1+2$, contamination latency $L$ (i.e., the time elapsed until half of the colony was in state 1 or 2 ), $D, n_{f}$, and $n_{T}$. For the initial infection regime, some simulations never reached a state where half of the bees were contaminated or infected. In this case we used one-way ANOVAs to test the effect of $P_{D}$ on contamination latency $L$ for each value of $T_{d}$ (Table S1).

\section{Results}

\subsection{Effect of immune response duration}

We explored the effect of the immune response duration $\left(T_{d}=2,5,20,200,500\right)$ and the probability to engage in a social immune response $\left(P_{D}=0.0,0.01,0.05,0.25,0.5,0.75,1\right)$ on pathogen spread (state 1 , state 2 , state $1+2$, contamination latency $L$ ), colony nutritional performance (the lower $D$ the higher the performance) and colony foraging effort $\left(n_{f}, n_{T}\right)$. Here we focussed on the initial contamination regime only (Table 2) and a relatively slow pathogen spread $\left(P_{s}=0.0025\right)$, where a majority of the workers is contaminated or infected within the simulated time (Fig. 2). Simulations with the continuous infection regime yielded similar results (Fig. S1, Table S2).

The immune response duration $\left(T_{d}\right)$, the probability to engage in a social immunity $\left(P_{D}\right)$ and their interaction had a significant effect on pathogen spread (Table 2; for the effect of $P_{D}$ on contamination latency $L$ see Table S1). Long immune responses $\left(T_{d}=200,500\right)$ resulted in the lowest level of pathogen spread (Fig. 2) and the lowest colony foraging effort (Fig. 3). In these conditions, there was no clear effect of engaging in social immune response.

By contrast, short immune responses $\left(T_{d}=2,5,20\right)$ resulted in a much stronger pathogen spread, with larger numbers of contaminated workers (state $1+$ state 2 individuals) due to the higher proportions of infected workers (state 2 individuals) and the shorter contamination latencies $(L)$ than for long immune responses (Table S1). The colony foraging effort ( $n_{f}$ and $n_{T}$ ) was also higher (Fig. 3). In these conditions, increasing the probability to engage in a social immune response $\left(P_{D}\right)$ led to a significant reduction of pathogen spread and foraging effort, down to similar values to those obtained for long immune responses (Fig. 3). The average nutritional performance of insects $(D)$ was always higher (lower $D$ ) in the presence of social immunity $\left(P_{D}>0\right)$ than without social immunity $\left(P_{D}=0\right)$. Therefore, social immunity, by which foragers adjust their nutrient intake to address the needs of their infected nestmates, is an efficient mechanism to reduce pathogen spread when immune responses are short.

\subsection{Effects of pathogen virulence}

Social insect infected by parasites often show impaired foraging behaviours (Gómez-Moracho et al., 2017), which suggests a reduced food intake at the colony level. Here we explored the consequences of foraging impairment on pathogen spread by varying the probability for infected foragers (state 2 workers) to fail foraging $\left(P_{f}=0.0,0.1,0.35\right.$, $0.5,0.75)$ for slow pathogen transmission $\left(P_{s}=0.0025\right.$, i.e. same value as in the previous section), and fast pathogen transmission $\left(P_{s}=0.01\right)$.

At a slow pathogen transmission rate $\left(P_{s}=0.0025\right)$, increasing the probability of failing foraging $\left(P_{f}\right)$ was generally beneficial to the colony. Colonies experienced reduced numbers of contaminated individuals (state 1 and 2 workers; Fig. 4a) and longer contamination latencies ( $L$; Fig. 4c). Here, the impaired activities of foragers only induced a slight decrease of the colony nutritional performance $(D$; Fig. 5a) and an increase of the foraging effort ( $n_{f}$ and $n_{T}$; Fig. $5 \mathrm{~b}$ and c).

Interestingly the results were markedly different at a fast pathogen transmission rate $\left(P_{s}=0.01\right)$. In these conditions, the pathogen almost always contaminated the entire colony (average number of state $1+2$ workers: $498.64 \pm 2.95$ (mean $\pm \mathrm{SD}$ )) within the simulated time. Increasing the probability of failing foraging $\left(P_{f}\right)$ led to an increased number of infected workers (state 2 workers; Fig. $4 \mathrm{~b}$ ), up to nearly the whole population (average number of state 2 workers: $489.32 \pm 7.35$ (mean \pm SD) ) being infected for frequent foraging failure of contaminated individuals $\left(P_{f}=0.75\right)$. The contamination latency $(L)$ was generally low and increased with $P_{f}$ (Fig. $4 \mathrm{c}$ ), indicating that while the final spread of the pathogen reached catastrophic levels, the early stages of the contamination were still partly delayed when infected foragers often failed to bring food back to the colony. Frequent foraging failure $\left(P_{d}=0.75\right)$ led to a very marked decrease in colony nutritional performance (higher $D$ ) up to an average level that was approximately five times lower than for other values of $P_{f}$ (Fig. 5a). The effect of $P_{f}$ on the foraging effort was also very pronounced. Increasing $P_{f}$ led to a recruitment of much higher numbers of foragers $\left(n_{f}\right.$; Fig. $\left.5 \mathrm{~b}\right)$ and an exponentially growing number of cumulated foraging trips throughout the simulations $\left(n_{T}\right.$, Fig. $5 c$ ). Therefore, while high probabilities of failing foraging were beneficial to colonies at low transmission rates, by removing infected individuals and limiting pathogen spread, high probabilities of failing foraging were highly detrimental at fast transmission rates, by reducing social immunity and accelerating colony declines. 
Table 2

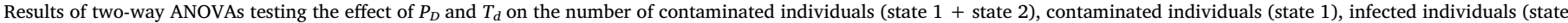
2), number of foragers $n_{f}$ and total number of foraging trips $n_{T}$, for an initial contamination regime. Parameters and variables are defined in Table 1 .

\begin{tabular}{|c|c|c|c|c|c|}
\hline Source & SS & df & MS & $\mathrm{F}$ & $\mathrm{p}$ \\
\hline \multicolumn{6}{|c|}{ Variable: number of contaminated and infected individuals (state $1+2$ ) } \\
\hline$P_{D}$ & 237699.9 & 6 & 39616.6 & 77.08 & $3.391 \mathrm{E}-94$ \\
\hline$T_{d}$ & 627124.9 & 4 & 156781.2 & 305.05 & $5.56 \mathrm{E}-246$ \\
\hline Interaction & 174465 & 24 & 7269.4 & 14.14 & $2.921 \mathrm{E}-56$ \\
\hline Error & 4479056 & 8715 & 513.9 & & \\
\hline Total & 5518346 & 8749 & & & \\
\hline \multicolumn{6}{|c|}{ Variable: number of state 1 individuals } \\
\hline$P_{D}$ & 427.9 & 6 & 71.317 & 1.08 & 0.3689 \\
\hline$T_{d}$ & 2738.4 & 4 & 684.588 & 10.41 & 0 \\
\hline Interaction & 3024.9 & 24 & 126.039 & 1.92 & 0.0045 \\
\hline Error & 573019.9 & 8715 & 65.751 & & \\
\hline Total & 579211.1 & 8749 & & & \\
\hline \multicolumn{6}{|c|}{ Variable: number of state 2 individuals } \\
\hline$P_{D}$ & 230031.5 & 6 & 38338.6 & 106.25 & $1.11 \mathrm{E}-129$ \\
\hline$T_{d}$ & 547890.9 & 4 & 136972.7 & 379.6 & $7.33 \mathrm{E}-302$ \\
\hline Interaction & 182613.1 & 24 & 7608.9 & 21.09 & $5.856 \mathrm{E}-89$ \\
\hline Error & 3144675 & 8715 & 360.8 & & \\
\hline Total & 4105211 & 8749 & & & \\
\hline \multicolumn{6}{|l|}{ Variable: $D$} \\
\hline$P_{D}$ & 0.00176 & 6 & 0.00029 & 14.68 & 0 \\
\hline$T_{d}$ & 0.00051 & 4 & 0.00013 & 6.32 & 0 \\
\hline Interaction & 0.00047 & 24 & 0.00002 & 0.97 & 0.5018 \\
\hline Error & 0.17433 & 8715 & 0.00002 & & \\
\hline Total & 0.17706 & 8749 & & & \\
\hline \multicolumn{6}{|l|}{ Variable: $n_{f}$} \\
\hline$P_{D}$ & 4265.1 & 6 & 710.85 & 17.86 & $1.099 \mathrm{E}-20$ \\
\hline$T_{d}$ & 9059.4 & 4 & 2264.86 & 56.89 & $1.858 \mathrm{E}-47$ \\
\hline Interaction & 4065.2 & 24 & 169.38 & 4.25 & $1.572 \mathrm{E}-11$ \\
\hline Error & 346955.7 & 8715 & 39.81 & & \\
\hline Total & 364345.4 & 8749 & & & \\
\hline \multicolumn{6}{|l|}{ Variable $n_{T}$} \\
\hline$P_{D}$ & $5.10 \mathrm{E}+09$ & 6 & $8.51 \mathrm{E}+08$ & 39.45 & $1.297 \mathrm{E}-47$ \\
\hline$T_{d}$ & $1.69 \mathrm{E}+10$ & 4 & $4.23 \mathrm{E}+09$ & 196 & $3.46 \mathrm{E}-161$ \\
\hline Interaction & $3.94 \mathrm{E}+09$ & 24 & $1.64 \mathrm{E}+08$ & 7.61 & $4.611 \mathrm{E}-26$ \\
\hline Error & $1.88 \mathrm{E}+11$ & 8715 & $2.16 \mathrm{E}+07$ & & \\
\hline Total & $2.14 \mathrm{E}+11$ & 8749 & & & \\
\hline
\end{tabular}

\section{Discussion}

Many insects adjust their nutrient intake to combat pathogens and parasites (Lee et al., 2006; Povey et al., 2009; Povey et al., 2014). Here we explored how such self-medication behaviour could scale up to a social insect colony, where individuals forage for their nestmates and dynamically balance their collection of multiple nutrients to reach a colony-level intake target. Based on recent advances in nutritional geometry modelling (Lihoreau et al., 2014, 2015), we developed an individual-based model to explore the consequences of dietary collective medication in hypothetical social insect colonies infected by a horizontally transmitted parasite that impairs the foraging behaviour of workers.
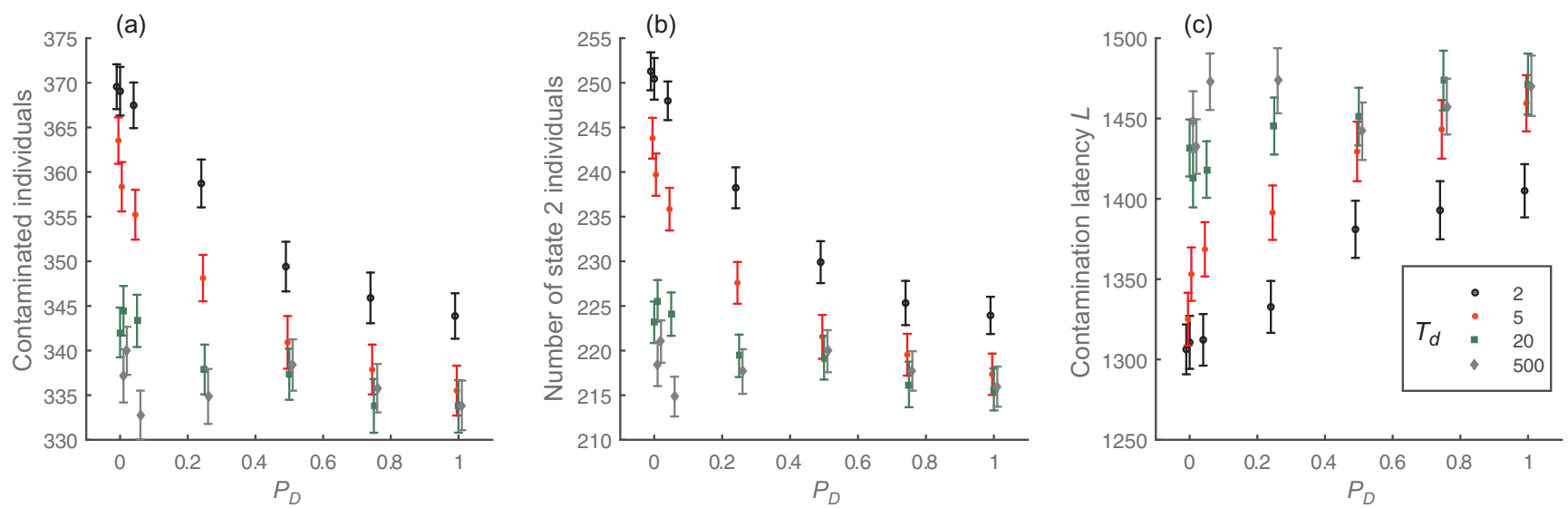

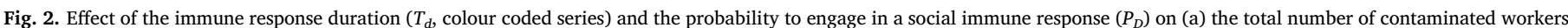

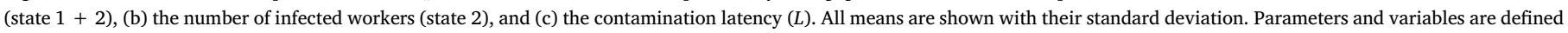
in Table 1. 

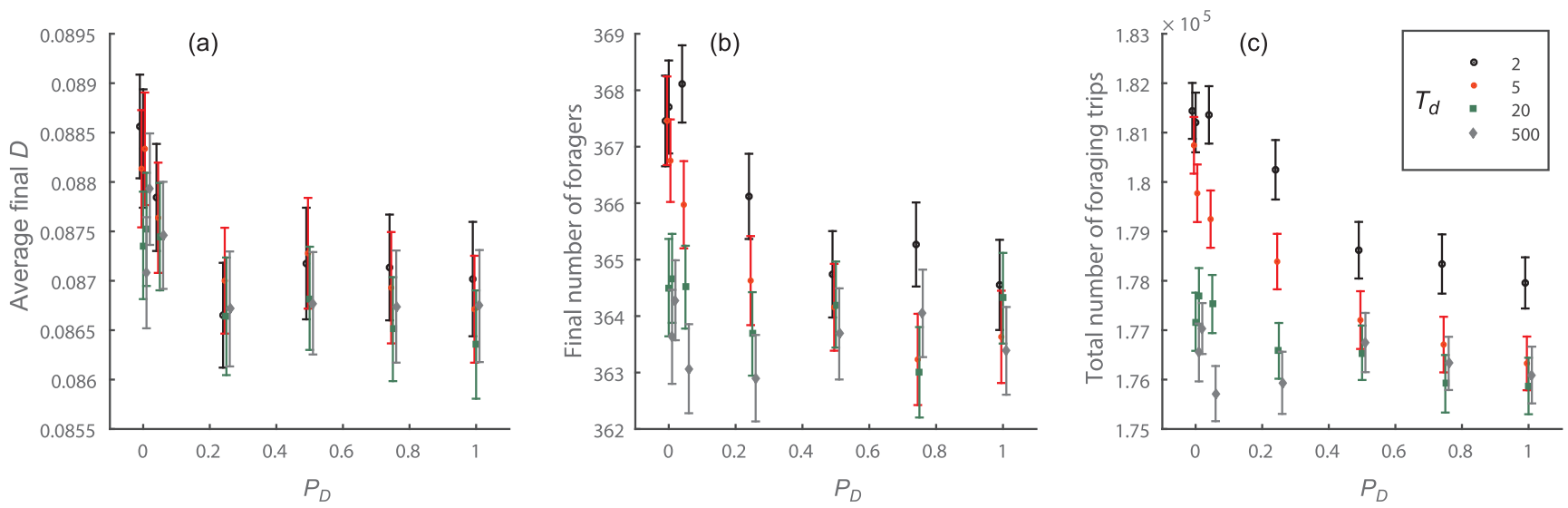

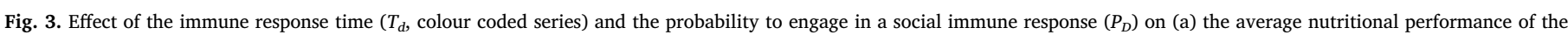

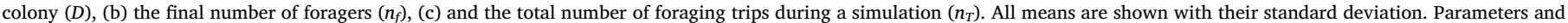
variables are defined in Table 1.

\subsection{Collective nutrition can efficiently limit pathogen spread}

Several recent models have considered the effects of pathogens and parasites on colony dynamics (Becher et al., 2014; Horn et al., 2016). Social insects are known to prophylactically collect anti-pathogen nonfood materials such as resins to prevent contaminations of parasites and pathogens (Christe et al., 2003; Chapuisat et al., 2007; Simone et al., 2009; Simone-Finstrom et al., 2012). However, none of these studies have considered the potential role of nutrition, and in particular the interacting effects of specific nutrients, in mitigating these effects. Our theoretical exploration of dietary medication based on nutritional geometry suggests that collective nutrition is a potentially efficient social immunity mechanism to limit pathogen spread in a colony. This is true especially when immune responses are short, which is typically the case for innate immune responses in insects (Schmid-Hempel, 1998). Through social immunity, foragers can adjust their nutrient intake to address the needs of infected nestmates and prepare themselves to fight a potential contamination.

Although the basic assumption that social insects make dietary medication decisions remains to be empirically validated, several recent studies suggest that all the ingredients are met. In bees for instance, mounting evidence show that workers accurately balance their intake of macronutrients to address their nutritional needs at the individual (Altaye et al., 2010; Stabler et al., 2015) and collective (Hendriksma and Shafir, 2016; Vaudo et al., 2016b) levels. Additionally, foragers are known to exploit secondary metabolites in plant products with anti-microbial properties in order to combat pathogens (Erler et al., 2014; Manson et al., 2010; Baracchi et al., 2015). Similar observations have been made in ants (Christe et al., 2003; Chapuisat et al., 2007; Dussutour and Simpson, 2009; Cook et al., 2010).
Importantly, individual-based models such ours are a powerful mean to generate well-defined predictions for empirical testing using experiments with nutritional geometry designs (Lihoreau et al., 2015).

\subsection{Foraging impairment limits pathogen spread at slow transmission rates}

Our theoretical exploration of dietary collective medication also suggests interesting consequences of behavioural changes in infected foragers for the colony health. For instance, infected honey bees often spend more time outside the colony and sometimes even never come back (e.g. Kralj and Fuchs, 2010; Dussaubat et al., 2013). Such behaviour may reflect impaired cognitive capacities that reduce the orientation performances of honey bee foragers or a host manipulation by the pathogen to favour its own spread (Schmid-Hempel, 2011). Reduced homing rates have also been interpreted as an altruistic 'selfremoval' strategy by which infected honey bees remove themselves from the colony to prevent disease transmission (Rueppell et al., 2010). Interestingly, our model suggests contrasted influences of impaired foraging on pathogen spread depending on its transmission rate. Inefficient infected foragers can benefit the colony provided that the pathogen does not spread fast enough, because their inability to feed nestmates or to return to the colony can act as a de facto quarantine mechanism. But if that quarantine effect of failing foragers is insufficient to stop the initial spread of the pathogen, there is a risk of failing to provide the colony with the adequate intake requirements necessary to engage its immune defence response. Therefore, affecting the foraging activity can either hinder or help its progression, depending on the specific effects of a pathogen, suggesting that different selection pressures may lead to similar behaviour depending on the host-pathogen system under consideration.
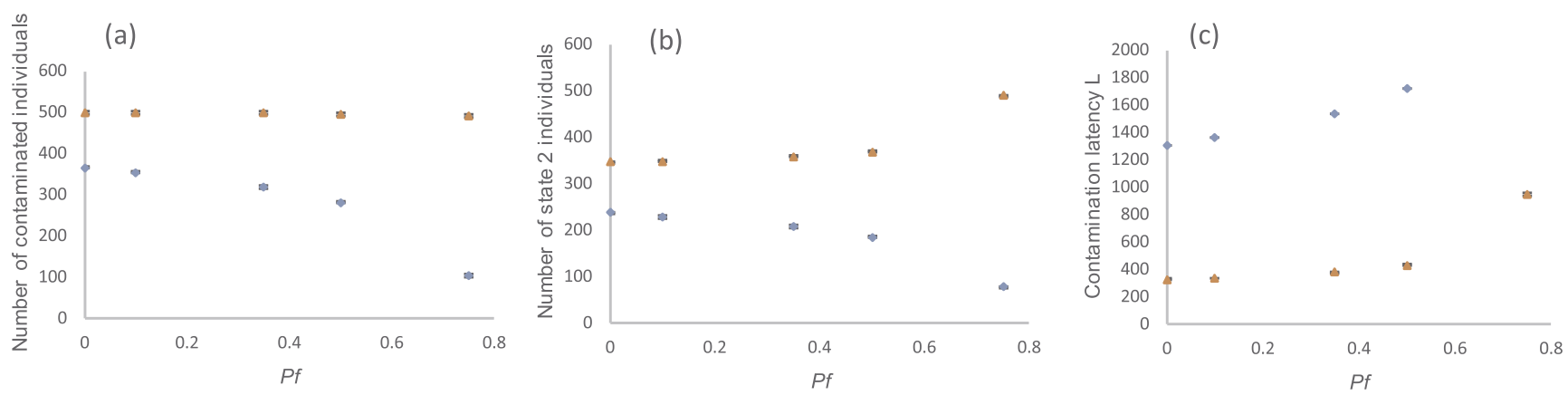

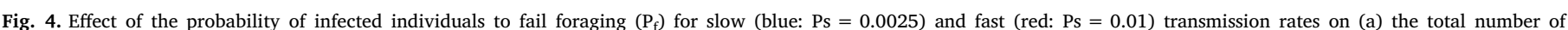

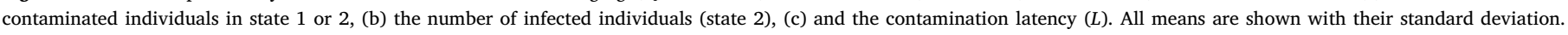
Parameters and variables are defined in Table 1. 

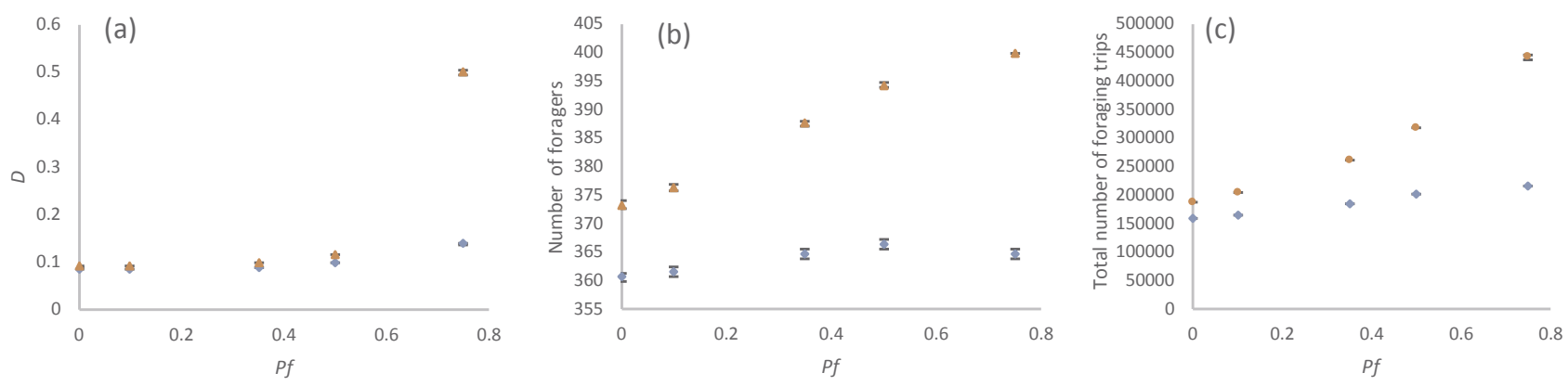

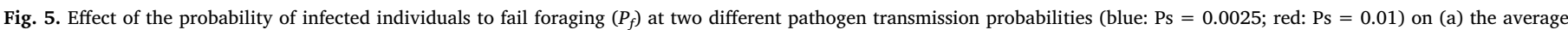

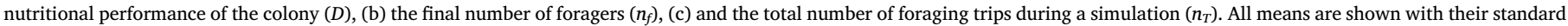
deviation. Parameters and variables are defined in Table 1.

\subsection{Implications for colony health}

An imbalanced nutrition is known to induce high mortality rates and colony collapse in social insects (Dussutour and Simpson, 2012). Over recent years, malnutrition has become particularly concerning in bees and is now considered a major cause of population declines, due to the lack of key nutrients for development, cognition or survival (Goulson et al., 2015; Klein et al., 2017). For instance, honey bees fed omega-3 poor pollen have reduced learning abilities, potentially incurring important foraging costs to colonies (Arien et al., 2016). Under natural conditions, when foragers fail in their collect food or disappear, more hive bees tend to become foragers and cease their hive-related activity, potentially translating into reduced brood care, defence and hygiene, as well as less efficient foraging efficiencies by the inexperienced foragers. Above a certain rate of forager disappearance, colony population may decrease dramatically and lead to an inevitable colony collapse (Khoury et al., 2011, 2013; Russell et al., 2013; Perry et al., 2015). Although purely theoretical, our study suggests that a failure in addressing the different nutritional needs of nestmates with various infection levels can have similar consequences.

Ultimately, accurate mapping of nutrient intake by infected bees and its consequences on colony functions, using our models, may allow for designing constructive interventions to limit these dynamics, for instance by providing infected colonies with appropriate plant resources that produce nectars and pollens that enable bees to self-medicate. Of course this would require some more development and precise parameterisation of our exploratory model, based on observations and experimental work. For instance, honey bee workers may use an "asymmetrical quadratic" rule of compromise when balancing carbohydrates and essential amino acids instead of the parsimonious nearest distance rule of compromise used here (Paoli et al., 2014). Bees also appear to balance their intake of lipids in pollen (Vaudo et al., 2016a,b) and mineral salt in water (Lau and Nieh, 2016) in addition to carbohydrates and protein. Importantly, all these adjustments are readily available in classical state-space models of nutritional geometry (Simpson and Raubenheimer, 2012) and can be implemented in our individual-based platform.

\subsection{Nutritional immunology of social animals}

Beyond identifying novel predictions about social insect-pathogen interactions, our model introduces a new framework for studying the nutritional immunology of social animals, by integrating models of epidemiology (Fefferman et al., 2007) and social nutrition (Lihoreau et al., 2014, 2015). This approach, here developed for a superorganism, could be expanded to a wider range of social species in which individuals make nutritional decisions for others, for instance when adults provision their brood or choose nesting environments that will provide nutrition for offspring. In principle, nutritional geometry models can be applied to many host-pathogen interactions in order to derive new empirically testable predictions, with only minimal fine tuning of the nutritional rules (number of nutritional dimensions, intake targets, rule of compromises, non-dietary foods), social rules (nature and frequency of interactions), and fitness consequences (impaired development and behaviour) for the hosts and the pathogens (Simpson et al., 2015a). A major challenge for host-pathogen research is to study these interactions from both perspectives (Schmid-Hempel, 2011). In the present case, the potential overlap of the nutritional changes required by the defence of the hosts and the nutritional requirements of the pathogens themselves may be critical. In honey bees, for instance, diets with higher pollen quantities increase $N$. ceranae intensity but also enhance the survival of honey bees (Jack et al., 2016). Models of nutritional geometry have already begun to explore these aspects by integrating the nutrient intake and fitness responses of multiple actors (hosts, pathogens, symbionts) and how they influence each other (Ponton et al., 2011; Wong et al., 2015). How these complex interactions scale up at the level of animal groups, where hosts interact with each other, remains an open question.

\section{Acknowledgements}

We thank to Spence Behmer and Jeri Wright for the invitation to write a manuscript in this special issue on Insect nutritional homeostasis in the Journal of Insect Physiology. We are also grateful to JulieAnne Popple and three anonymous reviewers for their comments on an earlier version of the manuscript.

\section{Funding}

This work was supported by the Australian Research Council (ARC) and the Centre National de la Recherche Scientifique (CNRS). Additionally ML receives funding from the IDEX of the Federal University of Toulouse and the Agence Nationale de la Recherche (ANR 16CE0200201). TGM receives funding from the Fyssen Foundation.

\section{Appendix A. Supplementary data}

Supplementary data associated with this article can be found, in the online version, at http://dx.doi.org/10.1016/j.jinsphys.2017.08.005.

\section{References}

Abbot, J., 2014. Self-medication in insects: current evidence and future perspectives. Ecol. Entomol. 39, 273-280.

Alaux, C., Crauser, D., Pioz, M., Saulnier, C., Le Conte, Y., 2014. Parasitic and immune modulation of flight activity in honey bees tracked with optical counters. J. Exp. Biol. 217, 3416-3424.

Alaux, C., Ducloz, F., Crauser, D., Le Conte, Y., 2010. Diet effects on honeybee immunocompetence. Biol. Lett. 6, 562-565.

Altaye, S.Z., Pirk, C.W.W., Crewe, R.M., Nicolson, S.W., 2010. Convergence of carbohydrate-biased intake targets in caged worker honeybees fed different protein sources. J. Exp. Biol. 213, 3311-3318

Arien, Y., Dag, A., Zarchin, S., Masci, T., Shafir, S., 2016. Omega-3 deficiency impairs 
honey bee learning. Proc. Natl. Acad. Sci. U.S.A. 51, 15761-15766.

Baracchi, D., Fadda, A., Turillazzi, S., 2012. Evidence for antiseptic behaviour towards sick adult bees in honey bee colonies. J. Insect Physiol. 58, 1589-1596.

Baracchi, D., Brown, M.J.F., Chittka, L., 2015. Behavioural evidence for self-medication in bumblebees? F1000Research 4, 73.

Becher, M.A., Grimm, V., Thorbek, P., Horn, J., Kennedy, P.J., Osborne, J.L., 2014. BEEHAVE: a systems model of honeybee colony dynamics and foraging to explore multifactorial causes of colony failure. J. Appl. Ecol. 51, 470-482.

Behmer, S.T., 2009. Animal behaviour: feeding the superorganism. Curr. Biol. 19, R366-R368.

Büchler, R., Drescher, W., Tornier, I., 1992. Grooming behaviour of Apis cerana, Apis mellifera and Apis dorsata and its effect on the parasitic mites Varroa jacobsoni and Tropilaelaps clareae. Exp. Appl. Acarol. 16, 313-319.

Chapuisat, M., Oppliger, A., Magliano, P., Christe, P., 2007. Wood ants use resin to protect themselves against pathogens. Proc. R. Soc. B 274, 2013-2017.

Christe, P., Oppliger, A., Bancalà, F., Castella, G., Chapuisat, M., 2003. Evidence for collective medication in ants. Ecol. Lett. 6, 19-22.

Clayton, D.H., Wolfe, N.D., 1993. The adaptive significance of self-medication. Trends Ecol. Evol. 8, 60-63.

Cook, S.C., Eubanks, M.D., Gold, R.E., Behmer, S.T., 2010. Colony-level macronutrient regulation in ants: mechanisms, hoarding and associated costs. Anim. Behav. 79, 429-437.

Cremer, S., Armitage, S.A.O., Schmid-Hempel, P., 2007. Social Immunity. Curr. Biol. 17, R693-R702.

de Roode, J.C., Lefèvre, T., Hunter, M.D., 2013. Self-medication in animals. Science 340, 150-152.

de Grandi-Hoffman, G., Chen, Y., 2015. Nutrition, immunity and viral infections in honey bees. Curr. Opin. Insect Sci. 10, 170-176.

Dussaubat, C., Maisonnasse, A., Crauser, D., Beslay, D., Costagliola, G., Soubeyrand, S., Kretzchmar, A., Le Conte, Y., 2013. Flight behaviour and pheromone changes associated to Nosema ceranae infection of honey bee workers (Apis mellifera) in field conditions. J. Invertebr. Pathol. 113, 42-51.

Dussutour, A., Simpson, S.J., 2009. Communal nutrition in ants. Curr. Biol. 19, 740-744.

Dussutour, A., Simpson, S.J., 2012. Ant workers die young and colonies collapse when fed a high-protein diet. Proc. R. Soc. B. 279, 2402-2408.

Erler, S., Denner, A., Bobiş, O., Forsgren, E., Moritz, R.F., 2014. Diversity of honey stores and their impact on pathogenic bacteria of the honeybee, Apis mellifera. Ecol. Evol. 4, 3960-3967.

Feldhaar, H., 2014. Ant nutritional ecology: linking the nutritional niche plasticity on individual and colony-level to community ecology. Curr. Opin. Insect Sci. 5, 25-30.

Fefferman, N.H., Traniello, J.F.A., Rosengaus, R.B., Calleri Ii, D.V., 2007. Disease prevention and resistance in social insects: modeling the survival consequences of immunity, hygienic behavior, and colony organization. Behav. Ecol. Sociobiol. 61, 565-577.

Fouks, B., Lattorf, H.M.G., 2011. Recognition and avoidance of contaminated flowers by foraging bumblebees (Bombus terrestris). PloS One 6, e26328.

Goblirsch, M., Huang, Z.Y., Spivak, M., Colbourne, J., Lopez, J., 2013. Physiological and behavioral changes in honey bees (Apis mellifera) induced by Nosema ceranae infection. PLoS One 8, e58165.

Gómez-Moracho, T., Heeb, P., Lihoreau, M., 2017. Effects of parasites and pathogens on bee cognition. Ecol. Entomol. http://dx.doi.org/10.1111/een.12434.

Goulson, D., Nicholls, E., Botías, C., Rotheray, E., 2015. Bee declines driven by combined stress from parasites, pesticides, and lack of flowers. Science 347, 1255957.

Hendriksma, H.P., Shafir, S., 2016. Honey bee foragers balance colony nutritional deficiencies. Behav. Ecol. Sociobiol. 70, 509-517.

Higes, M., Meana, A., Bartolomé, C., Botías, C., Martín-Hernández, R., 2013. Nosema ceranae (Microsporidia), a controversial 21st century honey bee pathogen. Environ. Microbiol. Rep. 5, 17-29.

Hölldobler, B., Wilson, E., 2009. The Superorganism: The Beauty, Elegance, and Strangeness of Insect Societies. WW Norton \& Company.

Horn, J., Becher, M.A., Kennedy, P.J., Osborne, J.L., Grimm, V., 2016. Multiple stressors: using the honeybee model BEEHAVE to explore how spatial and temporal forage stress affects colony resilience. Oikos 125, 1001-1016.

Jack, C.J., Uppala, S.S., Lucas, H.M., Sagili, R.R., 2016. Effects of pollen dilution on infection of Nosema ceranae in honey bees. J. Insect Physiol. 87, 12-19.

Khoury, D.S., Barron, A.B., Myerscough, M.R., 2013. Modelling food and population dynamics in honey bee colonies. PLoS One 8, e59084.

Khoury, D.S., Myerscough, M.R., Barron, A.B., 2011. A quantitative model of honey bee colony population dynamics. PLoS One 6, e18491.

Klein, S., Cabirol, A., Devaud, J., Barron, A., Lihoreau, M., 2017. Why bees are so vulnerable to environmental stressors. Evol. Trends Ecol. http://dx.doi.org/10.1016/j. tree.2016.12.009.

Kralj, J., Fuchs, S., 2010. Nosema sp. influences flight behavior of infected honey bee (Apis mellifera) foragers. Apidologie 41, 21-28.

Lach, L., Kratz, M., Baer, B., 2015. Parasitized honey bees are less likely to forage and carry less pollen. J. Invertebr. Pathol. 130, 64-71.

Lau, P.W., Nieh, J.C., 2016. Salt preferences of honey bee water foragers. J. Exp. Biol. 219, 790-796.

Lee, K.P., Cory, J.S., Wilson, K., Raubenheimer, D., Simpson, S.J., 2006. Flexible diet choice offsets protein costs of pathogen resistance in a caterpillar. Proc. R. Soc. B. 273, 823-829.

Lee, K.P., Simpson, S.J., Clissold, F.J., Brooks, R., Ballard, J.W.O., Taylor, P.W., Soran, N., Raubenheimer, D., 2008. Lifespan and reproduction in Drosophila: new insights from nutritional geometry. Proc. R. Soc. B. 105, 2498-2503.

Lihoreau, M., Buhl, J., Charleston, M.A., Sword, G.A., Raubenheimer, D., Simpson, S.J., 2014. Modelling nutrition across organizational levels: from individuals to superorganisms. J. Insect Physiol. 69, 2-11.

Lihoreau, M., Buhl, J., Charleston, M.A., Sword, G.A., Raubenheimer, D., Simpson, S.J., 2015. Nutritional ecology beyond the individual: a conceptual framework for integrating nutrition and social interactions. Ecol. Lett. 18, 273-286.

Manson, J.S., Otterstatter, M.C., Thomson, J.D., 2010. Consumption of a nectar alkaloid reduces pathogen load in bumble bees. Oeclogia 162, 81-89.

Martín-Hernández, R., Botías, C., Barrios, L., Martínez-Salvador, A., Meana, A., Mayack, C., Higes, M., 2011. Comparison of the energetic stress associated with experimental Nosema ceranae and Nosema apis infection of honeybees (Apis mellifera). Parasitol. Res. 109, 605-612.

Mason, P.A., Smilanich, A.M., Singer, M.S., 2014. Reduced consumption of protein-rich foods follows immune challenge in a polyphagous caterpillar. J. Exp. Biol. 217, 2250-2260.

Mayack, C., Naug, D., 2010. Parasitic infection leads to decline in hemolymph sugar levels in honeybee foragers. J. Insect Physiol. 56, 1572-1575.

Natsopoulou, M., McMahon, D., 2014. Interspecific competition in honeybee intracellular gut parasites is asymmetric and favours the spread of an emerging infectious disease. Proc. R. Soc. B. 282, 20141896.

Naug, D., Smith, B., 2007. Experimentally induced change in infectious period affects transmission dynamics in a social group. Proc. R. Soc. B. 270, 699-708.

Nicolson, S.W., 2011. Bee food: the chemistry and nutritional value of nectar, pollen and mixtures of the two. Afr. Zool. 46, 197-204.

Paoli, P.P., Donley, D., Stabler, D., Saseendranath, A., Nicolson, S.W., Simpson, S.J., Wright, G.A., 2014. Nutritional balance of essential amino acids and carbohydrates of the adult worker honeybee depends on age. Amino Acids 46, 1449-1458.

Peck, M.D., Babcock, G.F., Alexander, J.W., 1992. The role of protein and calorie restriction in outcome from salmonella infection in mice. J. Parenter. Enter. Nutr. 16, $561-565$.

Perry, C.J., Søvik, E., Myerscough, M.R., Barron, A.B., 2015. Rapid behavioral maturation accelerates failure of stressed honey bee colonies. Proc. Natl. Acad. Sci. U.S.A. 112, 3427-3432.

Ponton, F., Wilson, K., Cotter, S.C., Raubenheimer, D., Simpson, S.J., 2011. Nutritional immunology: a multi-dimensional approach. PLoS Pathog. 7, e1002223.

Ponton, F., Wilson, K., Holmes, A., Raubenheimer, D., Robinson, K.L., Simpson, S.J., 2015. Macronutrients mediate the functional relationship between Drosophila and Wolbachia. Proc. R. Soc. B. 282, 20142029.

Povey, S., Cotter, S.C., Simpson, S.J., Lee, K.P., Wilson, K., 2009. Can the protein costs of bacterial resistance be offset by altered feeding behaviour? J. Anim. Ecol. 78, 437-446.

Povey, S., Cotter, S.C., Simpson, S.J., Wilson, K., 2014. Dynamics of macronutrient selfmedication and illness-induced anorexia in virally infected insects. J. Anim. Ecol. 83, $245-255$.

Rueppell, O., Hayworth, M.K., Ross, N.P., 2010. Altruistic self-removal of health-compromised honey bee workers from their hive. J. Evol. Biol. 23, 1538-1546.

Russell, S., Barron, A.B., Harris, D., 2013. Dynamic modelling of honey bee (Apis mellifera) colony growth and failure. Ecol. Modell. 265, 158-169.

Schmid-Hempel, P., 1998. Parasites in Social Insects. Princeton University Press.

Schmid-Hempel, P., 2011. Evolutionary Parasitology: The Integrated Study of Infections, Immunology, Ecology, and Genetics. Oxford University Press.

Schmid-Hempel, P., 2017. Parasites and their social hosts. Trends Parasitol. http://dx.doi. org/10.1016/j.pt.2017.01.003.

Senior, A.M., Charleston, M.A., Lihoreau, M., Buhl, J., Raubenheimer, D., Simpson, S.J., 2015. Evolving nutritional strategies in the presence of competition: a geometric agent-based model. PLoS Comput. Biol. 11, e1004111.

Senior, A.M., Lihoreau, M., Buhl, J., Raubenheimer, D., Simpson, S.J., 2016a. Social network analysis and nutritional behavior: an integrated modeling approach. Front. Psychol. 7, 18 .

Senior, A.M., Lihoreau, M., Charleston, M.A., Buhl, J., Raubenheimer, D., Simpson, S.J., 2016b. Adaptive collective foraging in groups with conflicting nutritional needs. R. Soc. Open Sci. 3, 150638

Simone, M., Evans, J.D., Spivak, M., 2009. Resin collection and social immunity in honey bees. Evolution 63, 3016-3022.

Simone-Finstrom, M.D., Spivak, M., James, R., Mesce, K., Tumlinson, J., 2012. Increased resin collection after parasite challenge: a case of self-medication in honey bees? PLoS One 7, e34601.

Simpson, S.J., Raubenheimer, D., 1993. A multi-level analysis of feeding behaviour: the geometry of nutritional decisions. Phil. Trans. R. Soc. B Biol. Sci. 342, 381-402.

Simpson, S.J., Clissold, F.J., Lihoreau, M., Ponton, F., Wilder, S.M., Raubenheimer, D., 2015a. Recent advances in the integrative nutrition of arthropods. Annu. Rev. Entomol. 60, 293-311.

Simpson, S.J., Le Couteur, D.G., Raubenheimer, D., 2015b. Putting the balance back in diet. Cell 161, 18-23.

Simpson, S.J., Raubenheimer, D., 2012. The Nature of Nutrition - A Unifying Framework From Animal Adaptation to Human Obesity. Princeton University Press.

Stabler, D., Paoli, P.P., Nicolson, S.W., Wright, G.A., 2015. Nutrient balancing of the adult worker bumblebee (Bombus terrestris) depends on the dietary source of essential amino acids. J. Exp. Biol. 218, 793-802.

Solon-Biet, S.M., Walters, K.A., Simanainen, U.K., McMahon, A.C., Ruohonen, K., Ballardn, J.W.O., Raubenheimer, D., Handelsman, D.J., Le Couteur, D.G., Simpson, S.J., 2015. Macronutrient balance, reproductive function, and lifespan in aging mice. Proc. Natl. Acad. Sci. U.S.A. 112, 3481-3486.

Starks, P.T., Blackie, C.A., Seeley, T.D., 2000. Fever in honeybee colonies. Naturwissenschaften 87, 229-231.

Ushitani, T., Perry, C., Cheng, K., Barron, A.B., 2016. Accelerated behavioural development changes fine-scale search behaviour and spatial memory in honey bees (Apis mellifera L.). J. Exp. 219, 412-418. 
Vance, J.T., Williams, J.B., Elekonich, M.M., Roberts, S.P., 2009. The effects of age and behavioral development on honey bee (Apis mellifera) flight performance. J. Exp. Biol. 212, 2604-2611.

Vanderplanck, M., Vereecken, N.J., Grumiau, L., Esposito, F., Lognay, G., Wattiez, R., Michez, D., 2017. The importance of pollen chemistry in evolutionary host shifts of bees. Sci. Rep. 7, 43058.

Vaudo, A.D., Patch, H.M., Mortensen, D.A., Tooker, J.F., Grozinger, C.M., 2016 a. Macronutrient ratios in pollen shape bumble bee (Bombus impatiens) foraging strategies and floral preferences. Proc. Natl. Acad. Sci. U.S.A. 113, E4035-E4042.

Vaudo, A.D., Stabler, D., Patch, H.M., Tooker, J.F., Grozinger, C.M., Wright, G.A., 2016b. Bumble bees regulate their intake of essential protein and lipid pollen macronutrients. J. Exp. Biol. 219, 3962-3970.
Waddington, K.D., Rothenbuhler, W.C., 1976. Behaviour associated with hairless-black syndrome of adult honeybees. J. Apic. Res. 15, 35-41.

Wolf, S., McMahon, D.P., Lim, K.S., Pull, C.D., Clark, S.J., Paxton, R.J., Osborne, J.L., 2014. So near and yet so far: harmonic radar reveals reduced homing ability of nosema infected honeybees. PLoS One 9, e103989.

Wong, A.C., Holmes, A., Ponton, F., Lihoreau, M., Wilson, K., Raubenheimer, D., Simpson, S.J., 2015. Behavioral microbiomics: a multi-dimensional approach to microbial influence on behavior. Front. Microbiol. 6, 1359.

Wells, T., Wolf, S., Nicholls, E., Groll, H., Lim, K.S., Clark, S.J., Swain, J., Osborne, J.L., Haughton, A.J., 2016. Flight performance of actively foraging honey bees is reduced by a common pathogen. Environ. Microbiol. Rep. 8, 728-737. 